\title{
TRIALS TO IMPROVE THE VIABILITY OF RABBIT SEMEN AT VARIABLE CONDITIONS OF PRESERVATION USING DIFFERENT DILUENTS
}

\author{
Rowida M.R., Osman,R.H. and \\ Mona H.Shaker. \\ Department of artificial insemination and embryo transfer \\ Animal Reproduction Research Institute, Giza Egypt.
}

\begin{abstract}
Ten sexually mature rabbit bucks of (NZW) were used in this study. The present study aimed to investigate the effect of some diluents and differents regimes of dilution and preservation on the viability of rabbit semen .

Semen was collected by an artificial vagina and evaluated for volume $(\mathrm{ml})$, individual motility $(\%)$; concentration of spermatozoa $\left(\mathrm{ml} \times 10^{6}\right)$; percentage of alive spermatozoa and total abnormalities by conventional technique. Pooled semen sample was divided into three parts, the first part was extended in Tris - egg yolk ( $\mathrm{pH}$ 6.9), the second part was extended in Trisegg yolk $(\mathrm{pH} 7.5)$ and the third part was extended in sodium chloride $(\mathrm{pH}$ 7.0). Each part again was subdivided into three portions; the first portion was incubated at $37^{\circ} \mathrm{C}$ for $3 \mathrm{hr}$.; The second portion was kept at $5^{\circ} \mathrm{C}$. for 48 $\mathrm{hr}$. and the third portion was frozen in French straws $(0.25 \mathrm{ml}$.) and stored in liquid nitrogen $\left(-196^{\circ} \mathrm{C}\right)$.

Our results revealed that the percentage of alive spermatozoa displayed a significant increase $(\mathrm{P}<0.05)$ at $37{ }^{\circ} \mathrm{C}$ in sodium chloride extender than the other extenders, while there were no significant differences in individual sperm motility in the three extenders at $37{ }^{\circ} \mathrm{C}$. . On the other hand the individual sperm motility signed a significant increase $(\mathrm{p}<0.05)$ in Tris-egg yolk extender with $\mathrm{pH} 6.9$ than the other extenders at $5^{\circ} \mathrm{C}$.

The post thawing motility was significantly higher $(\mathrm{P}<0.05)$ in Tris-egg yolk extended semen with $\mathrm{pH} 6.9$ than the other extended semen. The extended semen with sodium chloride reported a highly significant percentage in acrosomal defects than the other extended semen with different $\mathrm{pH}$.
\end{abstract}




\section{INTRODUCTION}

Artificial insemination is a biotechnological tool used for genetic improvement. It is used in all animal species with many purpose including production, planning and control breeding which is associated to maximize enterprise profitability. Rabbits are not the exception where the artificial insemination is applied with the same objectives. A limitation factor for rabbit artificial insemination spread in commercial level is related to semen preservation. Fresh diluted semen has been used but its quality can be maintained only for a short period of time. Alvarino et.al. (1996) proved that semen storage for short time less than 48 hours at temperature between $5^{\circ} \mathrm{C}$ $25^{\circ} \mathrm{C}$ was commonly adopted in practice.

Hafez (1980) proved that the $\mathrm{pH}$ of rabbit semen extender must be alkaline which is comparable to the $\mathrm{pH}$ (6.74-7.59) of rabbit semen (Amin et.al.,1983; El Sherbiny 1987).Rowida et.al (2004) used Tris extender with two different $\mathrm{pH}(6.9$ and 7.5$)$ and proved that Tris at $\mathrm{pH} 7.5$ gave the best result in fresh and chilled diluted semen than $\mathrm{pH}$ 6.9. Belloti (1986) reported that Tris- based extender had been successfully used for preservation of rabbit semen. Sodium chloride $0.9 \%$ at $\mathrm{pH} 7.0$ used successfully in A.I with fresh diluted semen (Rowida et.al. 2005 and Abdel Ghaffar 1992).

Artificial insemination is still practiced in a very limited scale in Egyptian rabbitry. One of the main constrain meet with the preservation of buck semen is the disability of this semen to be stored for long period of time without losses of its fertilizing capacity (Zidan et.al, 2002).

Frozen rabbit semen didn't show good results in intensive breeding therefore, the present study was done to investigate the effect of diluents (extenders) with variable $\mathrm{pH}$ under different temperatures and freezing processes to evaluate sperm motility, abnormalities, percentages of livability and acrosomal defects. 


\section{MATERIALS AND METHODS}

\section{Animals}

Ten sexually mature (New Zealand White) rabbit bucks were used. Bucks were housed in individual cages under a constant photoperiod of 16 hr. light phase. Temperature and humidity of the building were recorded. Bucks were fed on a commercial diet and water with nipple drinkers was adlibitum.

\section{Semen collection and evaluation}

Semen was collected twice weekly for Six weeks using an artificial vagina according to the method described by Evans and Maxwell, (1987).Semen ejaculates were individually evaluated microscopically and only ejaculates exhibiting active sperm motility (over 70\%) were pooled and extended with different extenders having different $\mathrm{pH}$ (Tris-egg yolk $\mathrm{pH} 7.5$, Tris-egg yolk $\mathrm{pH} 6.9$ and Sodium chloride $\mathrm{pH}$ 7). The final extension rate was 1 semen: 4 extender.

Table (1) Showed the Composition of extenders $/ 100 \mathrm{ml}$ distilled water

\begin{tabular}{|c|c|c|c|}
\hline Composition & $\begin{array}{l}\text { Tris-egg yolk } \\
\text { (pH 7.5) }\end{array}$ & $\begin{array}{l}\text { Tris-egg yolk } \\
\text { (pH 6.9) }\end{array}$ & $\begin{array}{c}\text { Sodium } \\
\text { Chloride (pH 7) }\end{array}$ \\
\hline $\begin{array}{l}\text { - Tris amino } \\
\text { methan/gm }\end{array}$ & 3.028 & 3.028 & - \\
\hline - Lactose/gm & 1.250 & - & - \\
\hline - Glucose/gm & - & 1.25 & - \\
\hline - Citric acid/gm & 1.520 & 1.53 & 0.09 \\
\hline - Sod. Chloride/gm & - & - & - \\
\hline - Egg yolk (ml) & 5.0 & 5.0 & 5.0 \\
\hline $\begin{array}{ll}\text { - } & \text { Penicillin }-\mathrm{G}- \\
& \text { Sodium (IU) }\end{array}$ & 5000 & 5000 & 5000 \\
\hline $\begin{array}{ll}\text { - } & \text { Streptomycin } \\
& \text { sulphate }(\mu \mathrm{gm})\end{array}$ & 5000 & 5000 & 5000 \\
\hline * Glycerol & $2 \%$ & $2 \%$ & $2 \%$ \\
\hline
\end{tabular}


Each diluent was subdivided into three portions:-

The first portion was incubated at $37^{\circ} \mathrm{C}$.for $3 \mathrm{hr}$ and the second portion was preserved at $5{ }^{\circ} \mathrm{C}$. for $48 \mathrm{hr}$, the percentages of sperm motility, dead and abnormal spermatozoa were estimated according to Salisbury et.al.; (1978). The third portion was processed for freezing. Extended semen was cooled gradually to $5{ }^{\circ} \mathrm{C}$. within $45 \mathrm{~min}$. and then equilibrated at $5^{\circ} \mathrm{C}$. for $2 \mathrm{hr}$. The semen was then loaded in plastic French straws $(0.25)$. The straws were exposed to liquid nitrogen vapor inside a foam box container $(45 \times 35 \times 18$ $\mathrm{cm}$.) containing 10 liters of liquid nitrogen, above the liquid nitrogen surface $4 \mathrm{~cm}$. for $15 \mathrm{~min}$. then plunged and stored in liquid nitrogen container (Hassan 1988).

The frozen straws were stored for at least $28 \mathrm{hr}$. before thawing and evaluation. They were thawed in a water bath at $37^{\circ} \mathrm{C}$.for $30 \mathrm{sec}$.to examine post thawing motility. Semen smears stained by fast green stain FCF according to Wells and Awa ( 1970 ) were used to examin acrosomal defects.

These trials were replicated 4 times for evaluation and statistical analysis.

\section{Statistical analysis:-}

The data were recorded and analyzed statistically by using analysis of variance according to Snedecor and Cochran, (1982) using the general model program of SAS (1990).

\section{RESULTS}

The obtained results are presented in table 2,3 and 4 .

Table 2 showed that a high percentages of sperm motility and alive spermatozoa in different diluents with variable $\mathrm{pH}$ but there was significant differences between them $(\mathrm{p}<0.05)$ in which the sodium chloride revealed a high percentages of alive spermatozoa ( $88.0 \pm 1.7,87.7 \pm 1.9$ and $86.7 \pm 1.7$ respectively).

The sperm abnormalities showed a high significant differences $(p<0.05)$ in Tris-egg yolk at $\mathrm{pH} 7.5$ more than other extenders ( $5.3 \pm 0.09,4.3 \pm 0.5$ and $3.8 \pm 09$ respectively). 
Table 3 revealed that the sperm motility in Tris-egg yolk at $\mathrm{pH} 7.5$ was increased significantly $(\mathrm{p}<0.05)$ than other diluents $(40.0 \pm 4.6,26.3 \pm 2.4$ and $23.8 \pm 3.8$ respectively) during preservation at $5^{\circ} \mathrm{c}$. after $48 \mathrm{hr}$.

Table 4 showed that acrosomal damage in Tris-egg yolk at pH 6.9 decreased significantly (p0.05) than the other extenders ( $23.3 \pm 3.28,24.7 \pm .88$ and $29.7 \pm 2.6$ respectively ). On the other hand the post thawing motility at zero $\mathrm{hr}$ increased significantly $(\mathrm{p}<0.05)$ with Tris -egg yolk at $\mathrm{pH} 6.9$ than Tris at $\mathrm{pH} 7.5$ and sodium chloride at ph $7.0(38.5 \pm 1.3,36.7 \pm 1.5$ and $35.0 \pm 4.7$ respectively ).

Table (2) Effect of different extenders with variable $\mathrm{pH}$ on the percentages of alive spermatozoa, Sperm motility and sperm abnormalities during incubation at $37^{\circ} \mathrm{C}$. for $3 \mathrm{hr}$.

\begin{tabular}{|c|c|c|c|}
\hline ParameterlExtender & $\begin{array}{c}\text { Tris egg-yolk } \\
(\mathrm{pH} 7.5)\end{array}$ & $\begin{array}{c}\text { Tris egg-yolk } \\
(\mathrm{pH} 6.9)\end{array}$ & $\begin{array}{c}\text { Sodium Chloride } \\
(\mathrm{pH} 7)\end{array}$ \\
\hline Alive sperm & $87.7 \pm 1.9 \mathrm{ab}$ & $86.7 \pm 1.7 \mathrm{bc}$ & $88.0 \pm 1.7 \mathrm{a}$ \\
\hline Sperm motility & $82.5 \pm 1.7 \mathrm{a}$ & $83.3 \pm 1.7 \mathrm{a}$ & $83.3 \pm 1.1 \quad \mathrm{a}$ \\
\hline Sperm abnormality & $5.3 \pm 0.09 \mathrm{a}$ & $4.3 \pm 0.5 \quad \mathrm{a}$ & $3.8 \pm 0.9 \quad \mathrm{~b}$ \\
\hline
\end{tabular}

- Means with different subscripts $a, b, \ldots$ within raws are significantly different at least $\mathrm{p}<0.05$

Table (3) Effect of different extenders with variable $\mathrm{pH}$ on the percentages of sperm motility during preservation at $5^{\circ} \mathrm{C}$. for $48 \mathrm{hr}$.

\begin{tabular}{|c|c|c|c|}
\hline $\begin{array}{c}\text { Parameter } \\
\text { Extender }\end{array}$ & $\begin{array}{c}\text { Tris egg-yolk } \\
(\mathrm{pH} \mathrm{7.5)}\end{array}$ & $\begin{array}{c}\text { Tris egg-yolk } \\
(\mathrm{pH} 6.9)\end{array}$ & $\begin{array}{c}\text { Sodium Chloride } \\
(\mathrm{pH} 7)\end{array}$ \\
\hline $0 \mathrm{hr}$. & $57.5 \pm 3.2 \mathrm{a}$ & $45.0 \pm 2.9 \mathrm{c}$ & $47.5 \pm 2.9 \mathrm{~b}$ \\
\hline $24 \mathrm{hr}$. & $51.3 \pm 3.2 \mathrm{a}$ & $38.8 \pm 1.3 \mathrm{~b}$ & $37.5 \pm 1.4 \mathrm{c}$ \\
\hline $48 \mathrm{hr}$. & $40.0 \pm 4.6 \mathrm{a}$ & $26.3 \pm 2.4 \mathrm{~b}$ & $23.8 \pm 3.8 \mathrm{c}$ \\
\hline
\end{tabular}

- Means with different subscripts $a, b, \ldots$ within raws are significantly different at least $\mathrm{p}<0.05$ 
Table (4) Effect of different extenders with variable $\mathrm{pH}$ on the percentages of acrosome defects and post thawing motility.

\begin{tabular}{|c|c|c|c|}
\hline $\begin{array}{c}\text { Parameter } \\
\text { Extender }\end{array}$ & $\begin{array}{c}\text { Tris egg-yolk } \\
(\mathrm{pH} 7.5)\end{array}$ & $\begin{array}{c}\text { Tris egg-yolk } \\
(\mathrm{pH} 6.9)\end{array}$ & $\begin{array}{c}\text { Sodium Chloride } \\
(\mathrm{pH} 7.0)\end{array}$ \\
\hline Acrosome defects & $24.7 \pm 0.88 \mathrm{~b}$ & $23.3 \pm 3.28 \mathrm{c}$ & $29.7 \pm 2.6 \mathrm{a}$ \\
\hline $\begin{array}{c}\text { Post thawing motility } \\
\text { at 0hr }\end{array}$ & $36.5 \pm 1.5 \mathrm{~b}$ & $38.5 \pm 1.3 \mathrm{a}$ & $35.0 \pm 4.7 \mathrm{c}$ \\
\hline $\begin{array}{c}\text { Post thawing motility } \\
\text { after1 hr }\end{array}$ & $19.16 \pm 1.53 \mathrm{a}$ & $16.66 \pm 2.11 \mathrm{c}$ & $18.57 \pm 0.92 \mathrm{~b}$ \\
\hline $\begin{array}{c}\text { Post thawing motility } \\
\text { after 2 hr }\end{array}$ & $11.66 \pm 2.11 \mathrm{a}$ & $7.5 \pm 1.12 \mathrm{c}$ & $8.57 \pm 0.92 \mathrm{~b}$ \\
\hline
\end{tabular}

- Means with different subscripts $a, b, \ldots$ within raws are significantly different at least $\mathrm{p}<0.05$

\section{DISCUSSION}

The sperm motility and alive spermatozoa showed a high percentages in different diluents with variable $\mathrm{pH}$ (Table 2) but there was a significant difference between them in which the sodium chloride revealed a high percentages of alive sperm and sperm motility $(88.0 \pm 1.7 \quad \& 83.3 \pm 1.1)$ respectively.

So high motility and alive spermatozoa percentages while decrease in the percentage of sperm abnormalities means that the three extenders ( Tris $\mathrm{pH}$ 6.9, Tris $\mathrm{pH} 7.5$ and Sodium chloride $\mathrm{pH}$ 7) was provided a suitable environment for spermatozoa at $37{ }^{\circ} \mathrm{C}$.

In Table 3 : The effective use of chilled semen for A.I. depends on the ability of extender to protect the spermatozoa during storage . One basic component of semen is biologically buffered to minimize $\mathrm{pH}$ substance due to metabolic by-products of sperm (Watson, 1990). Castellini,et.al.,( 1992) proved that inorganic buffer have a limited buffering capacity, whereas Tris extender are more appropriate for the storage of rabbit semen at low temperature.

Bautuchai and Tanpipat (1989), Zeidan et.al. (2002) and Rowida et.al. (2004) showed that high percentage of sperm motility, alive spermatozoa and low percentage of acrosome abnormality during preservation at $5^{\circ} \mathrm{c}$.Also sperm motility was decreased in the progression of incubation time up to 2 days. This phenomenon may be due to increase lactic acid accumulation as a 
result of sperm anaerobic metabolism in both the osmotic pressure and $\mathrm{pH}$ of the media which exerts a toxic effect on sperm cell ( Abdel- Salam,2002 and Rowida,2003).

Table 4 showed that acrosomal damage in Tris buffer extender with $\mathrm{pH} 6.9$ decreased significantly $(\mathrm{P}<0.05)$ than Tris buffer with $\mathrm{pH} 7.5$ and sodium Chloride with pH 7. This agrees with those of Kestin and Tekin (1994) and Zeidan et.al. (2002) .While post thawing motility increased significantly $(\mathrm{P}<0.05)$ with Tris buffer $\mathrm{pH} 6.9$ than Tris buffer $\mathrm{pH} 7.5$ and sodium chloride $\mathrm{pH}$ 7. In addition, Post thawing motility after $2 \mathrm{hrs}$ (Table 4) decreased significantly $(\mathrm{P}<0.005)$ with the advancement of incubation at $37^{0} \mathrm{c}$ up to 2 hr.. This in agreement with El-Gaafary et.al. (1993), Chen et,al. (1989) and Hassan (1988). The effect of hydrogen ion concentration on freezability of rabbit semen extended in Tris glucose buffer at $\mathrm{pH} 6.9$ was higher than at $\mathrm{pH}$ 7.5 and sodium chloride at $\mathrm{pH}$ 7.The present data indicates that $\mathrm{pH}$ higher than 6.9 was more harmful to rabbit spermatozoa. The changes in $\mathrm{pH}$ harm the spermatozoa would be produced by the drop on temperature (Salisbury et.al.,1978).

\section{Conclusion:}

The present results indicated that sodium chloride is effective as a diluent to obtain good results at $37{ }^{\circ} \mathrm{C}$. The Tris extender $\mathrm{pH} 7.5$ is of great value for preservation of rabbit semen at $5^{0} \mathrm{C}$. The Tris extender at $\mathrm{pH} 6.9$ is more efficient for maintaining a good quality frozen thawed rabbit semen.

\section{REFERENCES}

Abdel Ghaffar, A. El-sayed (1992): Some studies on the artificial insemination rabbits.PHD.thesis, Zagazig Uneversty.

Abdel-Salam, A.M. (2002): Studied on freezing of rabbit semen. MSc. Thesis, Faculty of Agriculture, zagazig UN, zagazig, Egypt.

Alvarino,J.M.R.,Lopez,F.J.; Delarco,J.A. and Delgado,F. ( 1996 ): Artificial insemination of rabbits with diluted semen stored of $24 \mathrm{hr}$.In; World Rabbit Cong., 6,1996. Tolouse,Anais. Tolouse ,2: 37- 40.

Amin,S.O., Anwar,A. and El-Zeiny,M. ( 1983 ): Semen characteristics of three breeds of rabbits and the use of two types of diluents. Egypt Poltry Sci., 3: $27-34$. 
Bantuchai,S. and Tanpipat,S. ( 1989) : Motility and viability of rabbit spermatozoa diluted in Tris-egg yolk and egg yolk citrate. Kaen Agricutural Journal, 18, $97-106$.

Bellotti,G.F.(1986):Artificial insemination in rabbit .Praxis Veterinarian ,Italy, 7:15-16.

Castellini,C.; Battaglini,M. and Lattaioli,P. (1992 ): effects of cryoprotectants and freezing on rabbit semen quality. J. Appl. Rabbit Res., 15: $431-438$.

Chen, y, yang, x.and Foot,R.H.(1989):Timed breeding of rabbits with fresh and frozen thawed semen and evidence of acrosome alteration following freezing and thawing.Anin.Reprod.sci.,18:35-41.

EI Gaafary, M.N., Rashwan,A.A. and Zenat,A.Ibrahim (1993) : Investigation on the deep freezing of rabbit semen in straws. Egyptian Ameican Conference on Physiology of animal production El-fayoum, Egypt, PP: $17-25$.

El-Sherbiny,A.M. ( 1987 ): Seasonal variations in seminal characteristics of rabbits. M.Sci., Thesis, Fac.Agr.,Ain Shams Univ.,Egypt.

Evans,G. and Maxwell,W.M.C. (1987): Salmon's artificial insemination of sheep and goats. Butterwarths pty limited, Australia.

Hafez,E.S.E. ( 1980 ): Reproduction of farm animals. $4^{\text {th }}$ Edition, L A A + Febiger,Pheladlephia, U.S.A.

Hassan, A. M. A. (1988): Studies on freezing of Rabbit semen. B. Sc. Agric. (Animal Production), Al-Azhar University.

Kestin,O. and Tekin,N. ( 1994 ) : The effect of acrosomal defects on fertility of frozen rabbit semen.Turk Veterinerlikve Hayvancilik Dergis, 18, $299-305$.

Rowida,M.R. (2003): A comparative study of different addetives of extended rabbit semen .J.Egypt.Vet.Med.Assoc.,63 (4);351-361.

Rowida.M.R.,El-Serief,R.H. and Seleem.T.S.T.(2005): Effect of incubation time of diluted rabbit semen and time of Gn-RH treatment of does on fertility trait. The $4^{\text {th }}$ inter. Con. on Rabbit prods. In Hot clin, sharm El-Sheikh, Egypt, 191-196.

Rowida,M.R. , Tayseer, I.M. and El-Sheltawi,M.A.F. ( 2004 ): Rabbit semen quality and fertilizing ability as affected by the $\mathrm{pH}$ of extender. J.Egypt.Vet.med.Assoc. 64 No.4: 137 - 147.

Salisbury,G.W.;Van Demark,N.L.and Lodge, J.R. (1978 ):Physiology of reproduction and artificial insemination of cattle. $2^{\text {nd }}$ ed.W.H. Freeman and Company San Francisco.

SAS (1990): SAS/STAT User's Guide (Version 6, $4^{\text {th }}$ ed.) SAS Inst.Inc.,Cary,NC. 
Snedecor,G.W. and W.G.Cochran (1982): Statistical Methods. $2^{\text {nd }}$ Ed. Iowa Univ.Press.Ames,Iowa.

Watson, P.F. (1990): Artificial insemination and preservation of semen. In: Lamming G.E. 9 Ed.) Marchall's Physiology of reproduction, Vol 2. Reproduction in Male.Churchill Livingstone editional, Edinburgh.

Wells,M.E. and Awa,O.A. (1970): New technique for assessing acrosomal characteristics of spermatozoa.J.Dairy Sci.,53: 227.

Zeidan,A.E.B.,Abdel-Kariem,M.A.,Mohamed,M.M. and Bahgat, L.B. ( 2002): $3^{\text {rd }}$ Sci.Con. on rabbit production in Hot climates, $8-11$ Oct. : $317-328$.

\section{محاولات لتحسين حيوية حيامن الأرانب تحت ظروف حفظ مختلفة}

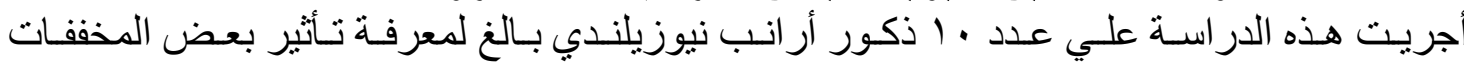

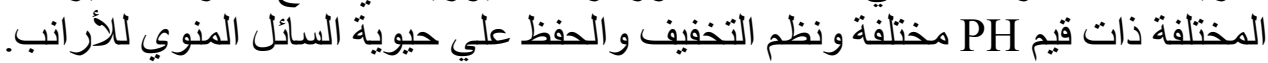

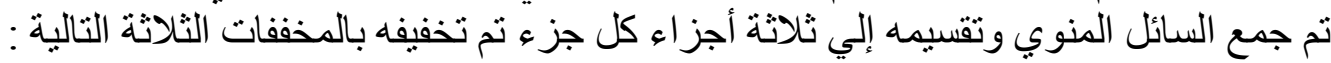

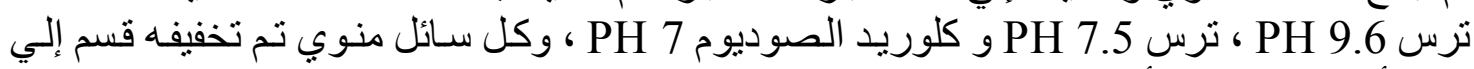

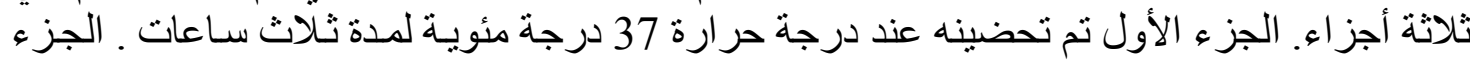

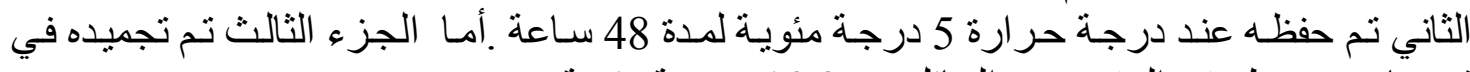

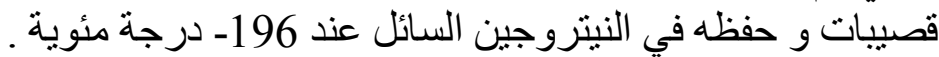

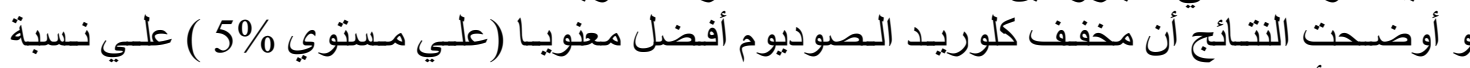

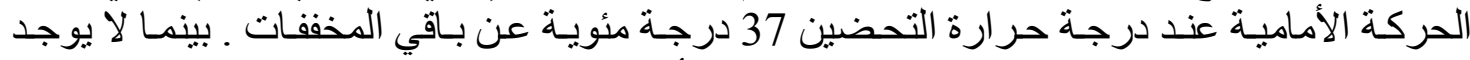

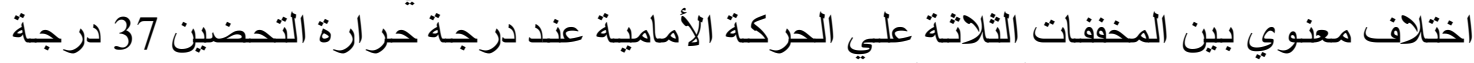

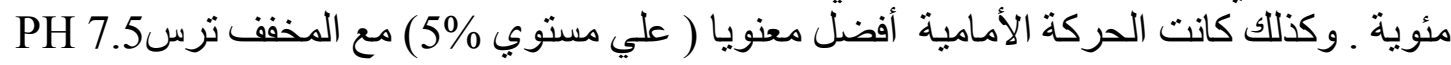

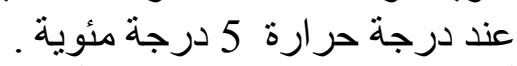

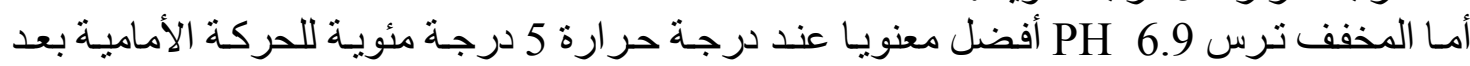

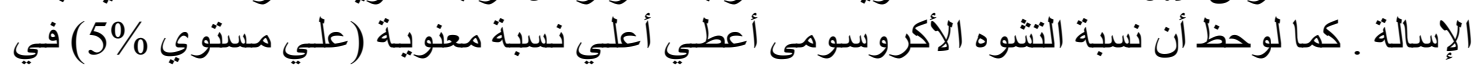
مخفف كلوريد الصوديوم. 